\title{
Technological knowledge and internationalization: Evidence from India
}

Dr. Saurabh Bhattacharya,

Senior Lecturer in Marketing, Newcastle University Business School, Newcastle, UK

Email: saurabh.bhattacharya@newcastle.ac.uk

Dr. Arpita Agnihotri, Assistant Professor of Management; Penn State Harrisburg, PA, USA

Email: axa671@psu.edu

Prof. Natalia Yannopoulou, Professor of Marketing, Newcastle University Business School, Newcastle, UK Email: natalia.yannopoulou@ncl.ac.uk 


\begin{abstract}
Purpose- The authors combine institutional theory with resource-based theory to explain how Emerging Market Firms (EMFs) manage their technological knowledge by venturing into international markets. The authors further explore the contingency effect of foreign market knowledge and competitive intensity in the home country in influencing the technological knowledge and internationalization relationship.

Design/methodology/approach- The study employs multiple linear regression analysis using a dataset consisting of 326 Bombay Stock Exchange-listed A and B category stocks for a six-year period (2010 to 2016).

Findings- The study finds that with an increase in technological knowledge, the internationalization of Indian firms increases. Furthermore, foreign market knowledge and competitive intensity positively moderate this relationship.

Research limitations/ implications - The study finds that with an increase in technological knowledge, the internationalization of Indian firms increases. Furthermore, foreign market knowledge and competitive intensity positively moderate this relationship. Thus, our research contributes to foreign market and knowledge management literature by demonstrating how institutional voids drive firms to internationalize when they possess rich technological knowledge.

Practical implications- Our findings increase foreign market managers' awareness of how internationalization acts as a knowledge management tool for EMFs under the contingency effect of foreign market knowledge and competitive intensity.
\end{abstract}

Originality/value - The study provides novel insights into EMFs' internationalization as driven by possession of technological knowledge. It further elaborates on the role of foreign market 
knowledge and competitive intensity in increasing firms' ability to manage technological knowledge through internationalization better.

Keywords: technological knowledge, foreign market knowledge, competitive intensity, internationalization

Paper type: Research paper 


\section{Introduction}

Knowledge-based resources are fundamentally critical to support firms' international market operations (Christofi et al., 2021; Vrontis et al., 2017; Vrontis and Christofi, 2019). From a foreign market perspective, technological knowledge is as critical as foreign market knowledge (Kaufmann et al., 2009; Li and Cavusgil, 1995). But how do firms, especially those from emerging markets suffering from institutional voids, manage this knowledge? Can possession of technological knowledge drive emerging market firms (EMFs) to internationalize, as the utility of such knowledge in the domestic market may lead to leakage given the poor legal environment in emerging markets?

Extant research has primarily leveraged the Uppsala model to explain the internationalization phenomenon of firms (Steen et al., 2007). However, in emerging markets, institutional theory has been more relevant to explain the internationalization of firms (Deng and Zhang, 2018). As per this theory, institutional constraints posed by the home country environment, such as institutional voids, drive the internationalization of EMFs. (Boisot and Meyer, 2008; Witt and Lewin, 2007). Most literature on internationalization from emerging markets has leveraged the institutional theory to explain how institutional policies or the perceived quality of home country institutions influenced the internationalization of EMFs, such that the poorer the perceived quality of the home country environment, more was the propensity to internationalize (Chan and Pattnaik, 2021; Yan et al., 2018).

Institutional quality also determines if valuable and rare technological resources possessed by firms are safe in the home country or are prone to espionage given the poor legal environment in emerging markets (Deng and Zhang, 2018). If institutional voids exist in the home country, then according to the institutionalization theory, as firms' technological knowledge increases, they 
should internationalize more. This is to leverage their knowledge safely in international markets and simultaneously expand the market. This reflection of institutional quality in the technological knowledge utilization and EMFs internationalization relationship has not been explored in extant literature.

Furthermore, foreign market knowledge possession may help EMFs efficiently utilize technological knowledge in such markets, as firms will better understand the foreign market environment (Zhou, 2007). Despite the significance of both technological and foreign market knowledge, extant research has not explored how they interact to drive the internationalization of firms. Resource-based theory (Barney, 1991) suggests, firms that possess rare, imperfectly imitable, and non-substitutable resources are likely to compete better. Firms reach such arrangements when they integrate existing resources in a difficult-to-replicate manner. Thus, EMFs possessing technological knowledge can internationalize more when they also possess foreign market knowledge.

Given the fast internationalization of EMFs, which has even given them the title of emerging market multinationals, it is vital to understand if internationalization is driven by EMFs' need to manage technological knowledge, given this knowledge is only poorly protected in emerging markets, owing to institutional voids and market inefficiencies in these markets (Bortoluzzi et al., 2018; Khanna and Palepu, 2000).

A key argument of knowledge management literature is that for firms to remain at the forefront and earn a competitive edge, they need to have adequate capacity to develop, organize and utilize their knowledge-based assets (Chatterjee et al., 2021; GroÈnhaug and Nordhaug, 1992). Knowledge management literature also emphasizes the role of information systems and management tools, techniques, and measures in codifying and utilizing this knowledge. We assert 
that in a poor institutional environment like India, where institutions that enable and support market activity are underdeveloped, and the likelihood of opportunistic behavior and misappropriation of knowledge in the home country is high (Chauvel and Despres, 2002; Doh et al., 2017), firms effectively utilize their technological knowledge by expanding to international markets. In other words, for EMFs, internationalization itself could be a tool to manage and utilize knowledge-based assets.

Scholars have further highlighted the significance of contingency factors as enablers or deterrents of knowledge management in organizations (Lee and Choi, 2003). Certain significant situational factors provide an "alternative to universal principles of management while studying a phenomenon" (Bordoloi and Islam, 2012, p. 114), implying that a firm's ability to manage technological knowledge through internationalization would depend upon contingency factors.

From the international marketing perspective and leveraging resource-based theory (Barney, 1991), we assert that foreign market knowledge and competitive intensity in the home country would determine firms' abilities to manage knowledge through internationalization. Specifically, as firms' foreign market knowledge would increase, their ability to capitalize on technological knowledge through internationalization would also increase. In similar stead, as competitive intensity in the domestic market would increase, it would drive firms to manage their technological knowledge through internationalization to avoid chances of knowledge misappropriation and theft.

Overall, in this paper, leveraging institutional theory (institutional voids of emerging markets) (Bortoluzzi et al., 2014; Boso et al., 2018) and resource-based theory, we explore two research objectives: a) How internationalization is driven by EMFs possession of technological knowledge, and b) How foreign market knowledge and competitive intensity in domestic markets influence this relationship? 
Our paper contributes to the extant body of literature on international marketing in several ways. First, it enriches the understanding of how EMFs internationalization is driven by the need to manage and utilize their technological knowledge. Our findings suggest that diversifying to foreign markets could be the safest way to avoid misappropriation of the technological knowledge by other rivals in the industry operating in the institutional environment of EMFs filled with institutional voids (Khanna and Palepu, 2000). This way, our paper provides fresh empirical evidence on EMFs' management of technological knowledge, which has received scant attention in extant international marketing literature.

Second, this study explores foreign market knowledge's role as a moderator of technological knowledge and the internationalization relationship. Boso et al. (2017) asserted, "despite promising trajectories on international marketing strategy research on emerging market firms, an unresolved issue is the question of the extent to which international marketing activities of emerging market firms are truly emerging market originated" (p. 210). This paper attempts to resolve this issue by exploring how the combined effect of technological knowledge and foreign market knowledge of EMFs drive their internationalization.

Third, leveraging institutional theory, we explore the role of competitive intensity in influencing technological knowledge and internationalization relationship, where a plethora of extant literature studied its direct influence on firms' internationalization (Ipek and Tanyeri, 2020; Styles et al., 2006). When competitive intensity is high in voids-filled emerging markets, to avoid misappropriation of technological knowledge, EMFs internationalize even more.

We test our proposition on a sample of 326 Indian firms over six years, i.e., 2010-2016, using archival data from the Center for Monitoring Indian Economy (Prowess) database. The paper proceeds as follows. First, we briefly review the literature on technological knowledge, foreign 
market knowledge, and competitive intensity. We follow this by theoretical argument development. Next, we present our hypothesis on the research objectives. Following this is the methods section, in which we present the data collection procedure. We then offer the analysis and results. Finally, we conclude the paper with the theoretical and managerial implications and directions of future research.

\section{Literature review and research framework}

\subsection{Institutional theory for EMFs}

As the global economy experienced a dramatic shift in emerging market firms' economic activities, they received significant scholarly discourse among international marketing scholars (Bortoluzzi et al., 2014). Emerging markets refer to low-income countries that have undergone rapid economic growth in recent years (Bruton et al., 2013; Wright et al., 2005). The waves of liberalizations, privatizations, and deregulations in emerging markets like India in the 1990s created a hyper-competitive environment for these firms (Adomako et al., 2019). Several EMFs began exploring growth opportunities abroad in the wake of developments and subsequent market reforms (Kumar and Agarwal, 2005). However, the institutional environment's quality deterred them from investing in technological knowledge development to serve better customer needs (Wadhwa et al., 2017).

The institutional theory offers a useful theoretical framework for understanding institutional challenges in developing and emerging markets (Stewart Jr et al., 2008; Wright et al., 2005). Institutions are defined as "the rules of the game in a society or humanly devised constraints that shape human interaction" (North, 1990, p. 3). These consist of both formal and informal institutions (North, 1990; Scott, 1995). According to Mair and Marti (2009, p. 422), institutional 
voids are present in an environment when "institutional arrangements that support markets are absent, weak, or fail to accomplish the role expected of them."

Emerging markets suffer from these institutional voids, which is defined as "situations where important institutional arrangements needed to support markets (often 'western capitalist institutions') are either absent or too weak to perform in the same manner as seen in developed western economies" (Amaeshi et al., 2016; p. 136). Research suggests that these institutional voids increase the transaction cost of operating and managing knowledge in areas of weak institutions (Doh et al., 2017). Environments characterized by institutional voids entail high uncertainty rates and distrust among organizations, individuals, and/or groups and raise challenges for knowledge management in organizations, especially technological knowledge.

\subsection{Technological knowledge}

Technological knowledge refers to knowledge associated with products technologies, and/or processes (Burgers et al., 2008). The agglomeration of technological knowledge allows more efficient utilization of related knowledge and enables organizations to be better cognizant of the nature and commercialization potential of technological advances (Cohen and Levinthal, 1990).

The characteristics of the technological knowledge captivating the endowed technology can be categorized along three dimensions (Clarysse et al., 2011; Narayanan, 2001): scope/specificity, newness/cumulativeness, and tacitness. Scope of technological knowledge implies the degree to which one can use the same core knowledge/technology in different applications. The broader the scope of technology, the more the product lines in which firms can diversify. The second characteristic of technology is its newness or cumulativeness (Marsili and Verspagen, 2002). Newness reflects the extent of the technological innovation departs from existing technologies, 
products, and practices (Bierly III et al., 2009). The third characteristic, tacitness, reflects the degree to which technology and its underlying knowledge are "tacit."

\subsection{Technological knowledge and institutional theory}

A significant and commonly shared perspective in knowledge management literature is that firms' technological knowledge utilization and management is enabled and supported by country-level institutions (Castellacci and Natera, 2012). For instance, financial institutions can offer firms' access to finance, thus making resources available to invest in technological knowledge; legal institutions and an efficient court system can drive commercial transactions, contract enforcement, and the protection of intellectual property rights (IPRs); and labor market regulations can attract a significant pool of talented human resources and determine the flexibility of the labor market as well as opportunistic behavior inculcated by this market.

Overall, the country's institutional environment emphasizes the significance of public institutions as a supportive framework for driving firms to develop technological knowledge (Castellacci, 2012). When the institutional environment is not fully developed, it results in the presence of institutional voids (Khanna and Palepu, 2000). Firms in such an environment are deterred from developing technological knowledge. Moreover, even if they have technological knowledge, its appropriate deployment becomes challenging due to the risk of misappropriation of technological knowledge ( $\mathrm{Li}$ and $\mathrm{Xie}, 2011)$. In such an environment, the most feasible way of exploiting technological knowledge is to quickly deploy it in international markets so that firms can reduce the chances of technology misappropriation and imitation by local competitors in the home market. As Shankar and Narang (2020) stated, "the weaker the intellectual property protection, the greater is the incentive for imitators to introduce more me-too products" (p. 1039). Given India's weaker intellectual property management environment (Khanna and Palepu, 2000), 
the best way to manage technological knowledge is likely to be internationalization. Thus, firms adopt internationalization as a strategic response to emerging markets' institutional environment (Adomako et al., 2020).

Overall, in institutionally stringent environments where institutional voids such as weak intellectual property rights, lack of transparency, red tape, bureaucracy, administrative delays, inadequate disclosure regime, corruption, and political instability exist, firms are more driven to exploit international market opportunities to appropriately and quickly deploy their technological knowledge (Acquaah, 2007; Jones, 2012). Thus, instead of learning about the domestic market, they may focus attention on international markets through internationalization. These constraints at home provide technological capital-rich EMFs an opportunity to use the home market as a “training ground" for international market expansion (Hitt et al., 2005), therefore, exploring new markets while also protecting and managing their technological knowledge. Although through other complementary mechanisms such as secrecy, exclusive know-how, lead time advantage, faster learning curve, etc., the value of the underlying technology in the absence of legal rights can be managed (Cohen et al., 2000), still internationalization provides a better mechanism to manage technological knowledge as knowledge need not be stored secretly but be exploited while satisfying consumer needs in international markets. Thus, EMFs rich in technological knowledge are more likely to internationalize swiftly to deploy and efficiently utilize their knowledge. Hence, we hypothesize:

H1. Technological knowledge is positively associated with firms' internationalization.

\subsection{The moderating role of competitive intensity}

Competitive intensity reflects the level of rivalry among firms belonging to the same industry where a firm's strategic actions are determined by the conditions of uncertainty and 
unpredictability set by the intensity of rivalry in the industry (Auh and Menguc, 2005). As conditions of intense competition affect a firm's behavior (Ang, 2008), it can reduce the level of profits firms can earn in the domestic market and the level of differentiation it can create in the home market, thus driving focal firms to look for expansion of their market in international countries.

Firms operating in technological fields often operate in complex, dynamic, and risky competitive conditions. Mohrman and Von Glinow (1990) stated, "The technological environment can simultaneously create new opportunities for entry, bankrupt existing companies, and render obsolete entire product lines and manufacturing and design processes overnight" (p. 264). Overall, developing technological knowledge is particularly important in a dynamic, discontinuous, and complex competitive landscape.

In emerging markets, the competitive landscape also creates challenges for technological knowledge utilization and management. A big concern for EMFs with technical knowledge assets is whether they can protect their ideas, technology, plans, processes, and other original creations from theft. A weaker IPR regime or the presence of institutional voids can increase competitors' imitative ability (Smith, 2001). Under conditions of superior IPR protection, firms would be able to best exploit their technical knowledge assets by exercising market power, i.e., raising prices with little risk of competitive imitation or misappropriation of technology. However, in emerging markets, where IPR (Intellectual Property Right) is only weakly protected, misappropriation risk arises by misuse of intellectual property (IP) (Berger et al., 2012).

Competitive intensity, in general, is a double-edged sword. On the one hand, it can drive firms to create more knowledge and differentiate from competitors; on the other hand, it could also create risks for firms to manage the newly created knowledge. Under a weaker IPR regime and the 
presence of institutional voids, a higher competitive intensity would discourage firms from utilizing their technological knowledge in their home country. This is because, when competitive intensity is high, chances of technology misappropriation by competitors will increase (Gast et al., 2019). Poor IPR regime environment of emerging markets, filled with institutional voids, will make the protection of such technology more challenging. Thus, increasing competitive intensity would drive firms to utilize technological knowledge assets by expanding to international markets (Jiang and Menguc, 2012). Otherwise, competitors will imitate the technology faster in a highly competitive environment and launch their version of innovative products. As competitive intensity increases, imitation risk would also increase, thus driving firms with knowledge assets to expand more in international markets. Hence, we hypothesize:

H2. Competitive intensity in the home country moderate firms' technological knowledge and internationalization relationship.

\subsection{The moderating role of foreign market knowledge}

Firms differ in their knowledge management capabilities depending on their strategic orientation or prospector orientation (Griffith et al., 2012). However, different types of knowledge may also interact to influence knowledge management capability. We explore the role of foreign market knowledge in influencing the management of technological knowledge.

Foreign market knowledge implies a firm's set of skills and knowledge of international markets and customer needs and its ability to forecast and respond to those needs (Song et al., 2008). In a way, they represent autotelic capabilities (Karagouni et al., 2013), the richness of which can be considered as a strategic resource given it is distinct for each firm (Song et al., 2008) and has a tacit, path-dependent, and causally ambiguous nature, making it a source of competitive advantage (Krasnikov and Jayachandran, 2008). 
Foreign market knowledge is an important driver of internationalization as it strengthens a firm's ability to capitalize on market opportunities (Zou et al., 2003). While internationalizing, firms must enhance their market knowledge (O'Cass et al., 2015). When technological knowledge assets drive firms to internationalize to avoid expropriation of assets, foreign market knowledge related to targeting customers, setting prices, or building relationships with customers and other channel members could further enhance the firms' ability to deploy their technological knowledge through internationalization. This is because EMFs with greater foreign market knowledge are more likely to have apriori insights into foreign firms' marketing practices. Through their ties with different economic actors in foreign markets, such as importers, exporters, trade partners, buyers, competitors, and governments, managers can gain experiential insights about foreign markets, resulting in greater foreign market knowledge (Hånell et al., 2020). The buyer-supplier knowledge obtained (Choi et al., 2019) can be used to explore more efficient product designs or marketing strategies that foreign firms deploy in their home countries (Eriksson and Chetty, 1998; Ramani and Srinivasan, 2019; Vrontis et al., 2020). Thus, such prior foreign market knowledge may enhance firms' ability to deploy their technological knowledge in foreign markets.

Furthermore, foreign market knowledge can increase EMFs' awareness of foreign firms' abilities and superiority, thus helping them better differentiate and more effectively deploy technological knowledge in international markets (Ramani and Srinivasan, 2019). Extant research (Goldberg et al., 2009; MacGarvie, 2006) suggests that firms can capture foreign sellers' experience by importing inputs from them and gaining knowledge about foreign customers' practices and processes by exporting goods and services to them (Theodosiou and Katsikea, 2013; Vrontis et al., 2012). With this knowledge, firms would respond to market requirements and develop technological knowledge based on anticipated changes in market conditions (Day, 1994). 
Strong foreign market knowledge can strengthen the technological knowledge and internationalization relationship (Mariadoss et al., 2011). This is because foreign market knowledge helps firms establish a unique position through differentiation and brand-building efforts for foreign customers (Mostafiz et al., 2021). Thus, foreign market knowledge could stimulate demand in international markets, establish channels in these markets through liasoning, etc., thus putting firms better positioned to deploy their technological assets in international markets through internationalization.

Overall foreign market knowledge can help firms deploy their technological knowledge in international markets more efficiently and thus make it easy and less challenging for firms with knowledge capital to internationalize. Hence, we hypothesize:

H3. Foreign market knowledge moderates firms' technological knowledge and internationalization relationship.

The conceptual framework is presented in Figure 1.

\section{Insert Figure 1 about here}

\section{Data and Methods}

In the present study, we collected data from Group "A" and Group "B" listed Indian firms on the Bombay Stock Exchange (BSE). Although several Asian nations are classified as developing economies with institutional voids, India has made a greater leap progressing its status from a "third world" country to a fast-growing "emerging economy." Several firms from India are 
referred to as emerging market multinationals, given the fast internationalization of the firms (Chittoor et al., 2007), thus making it an interesting context of the study. According to BSE's criterion, A and B categories listed firms scored well on parameters such as market capitalization, turnover, and financial information reporting. BSE A-listed firms are most actively traded on the stock exchange. BSE B-listed firms consist of all other listed firms that are neither blacklisted (category z) nor have any limitation on trading, such as intraday trading being not allowed (category T) (BSE India, 2011). Thus, excluding Z and T category firms, we considered category A and B listed firms on the stock exchange.

Furthermore, following extant research, we did not consider banks, foreign-owned and publicsector units. Excluding these firms resulted in a list of 1205 firms. Financial data for the firms was collected for a period of six years, i.e., from 2010-2016, from the financial database, Prowess of the Centre for Monitoring Indian Economy (CMIE). After filtering firms with available variables of interest, we were left with a sample of 326 firms and $326^{*} 6=1956$ firm years.

\subsection{Operationalization of variables}

\subsubsection{Dependent variable}

Following extant literature (Ray et al., 2018), we captured internationalization as firm's foreign assets to its total assets in a given year (Bhaumik et al., 2010; Chari, 2013). This captures a riskier, more involved, and high commitment internationalization mode. However, to explore the influence of technological knowledge on internationalization, we used growth in internationalization as the dependent variable. As investments in technological knowledge increase, a firm should internationalize more to protect the knowledge. Thus, we measured growth in internationalization as a firm's change in the ratio of foreign assets to the total assets. 


\subsubsection{Independent variable}

Technological knowledge (Net technical knowhow): We captured technological knowledge as the natural $\log$ of the firm's net technical knowhow. We obtained this information directly from CMIE Prowess.

Competitive intensity: First, based on the NIC 2-digit codes, we selected a firm's industry. Next, using Herfindahl Index as a measure, the competitive intensity was calculated. We employed 1 minus the Herfindahl Index (HERF = sum of squared market shares for all the firms in an industry). A high (low) value of the measure (i.e., 1 - HERF) indicates high (low) market competition (Engelen et al., 2012; Keats and Hitt, 1988; Lounsbury, 2002).

Foreign market knowledge: We operationalized foreign market knowledge as the ratio of the sum of foreign exchange spending and foreign exchange earnings divided by total assets, where forex earnings included the import of raw materials, stores and spares, finished goods, capital goods, and royalties (Ramani and Srinivasan, 2019).

Moderating effects: (Technological knowledge*Competitive intensity and Technological knowledge*Foreign market knowledge): We calculated these two interaction terms after mean centering all the variables and then multiplying the mean-centered values of the two variables with each other (Shieh, 2010).

\subsubsection{Control variables}

We controlled for the firm's age, size, leverage, financial slack, and business group affiliation. We also controlled for industry and year using dummy variables. We measured firm age as the natural $\log$ of the number of years since the focal firm's inception. We calculated firm size as the natural $\log$ of the number of employees. We controlled a firm's business group affiliation through a dummy variable coded as 1 when it was associated with the business group. We 
operationalized leverage as a debt-to-equity ratio. We measured financial slack using the current ratio (Ashwin et al., 2016).

\subsubsection{Controlling for endogeneity}

To control for endogeneity, we regressed technological knowledge on two variables, namely social and self-aspirational performance discrepancy, where social aspirational performance discrepancy was industry aspiration, i.e., firm's performance at $(\mathrm{t}-1)$ relative to the median performance of the firms in the same 2-digit NIC industry at t-2 (Chen and Miller, 2007). The firm-level aspirational performance discrepancy (self-aspirational performance discrepancy) was measured as its performance at $t-1$ relative to its performance at $t-2$. In both cases, the measure of performance is the return on assets (Guedes et al., 2016). Table 1 presents the variables' operationalizations.

\section{Insert Table 1 about here}

\section{Model specification and results}

We used the generalized least square (GLS) models for panel data, with correction for heteroskedasticity and autocorrelation to test our hypothesis. GLS is appropriate for the panel data analysis using random-effect models. It produces residuals that estimate the unit-specific serial correction of the errors associated with panel data (Beck and Katz, 1995; Greene, 2000). It also maximizes the degree of freedom (Lee et al., 2008). Moreover, it is commonly used in the extant literature to address the problems associated with panel data (Dau, 2012; Ray et al., 2018). We 
also confirmed the model by running the Hausman test, suggesting that the random effects models are adequate for our analysis.

Table 2 presents the descriptive statistics and correlation coefficients for the sample of 1,956 firm years. As can be observed from Table 2, there is a positive and significant correlation between technological knowledge and growth in foreign assets ratio $(\mathrm{r}=0.321, \mathrm{p}<0.01)$, thus presenting preliminary evidence supporting our first hypothesis.

Table 3 presents the results of the regression analysis. Model 0 is the based model in which we test the relationship between the control variables and internationalization. Business group affiliation $(\beta=0.078, \mathrm{p}<0.01)$ and financial slack $(\beta=0.073, \mathrm{p}<0.05)$ among control variables were found to be significant.

\section{Insert Table 2 about here}

\section{Insert Table 3 about here}

Next, in Model 1 of Table 3, we introduce the independent variables, followed by Model 2 of Table 3, in which we introduce the interaction terms. Our first hypothesis stated that technological knowledge is positively associated with internationalization. In Model 1 of Table 3, since the beta coefficient of technological knowledge is positive and significant $(\beta=0.193, p<0.001)$, we receive evidence supporting the first hypothesis. 
Our second hypothesis suggested that competitive intensity moderates technological knowledge and the internationalization relationship. In Model 2 of Table 3, since the beta coefficient of the interaction effect of technological knowledge and competitive intensity is positive and significant $(\beta=0.093, \mathrm{p}<0.01)$, we receive evidence supporting the second hypothesis. Since signs are difficult to interpret for moderating effects, we have depicted them through a graph presented in Figure 1. As shown in Figure 2, when competitive intensity (CI) is low, an increase in internationalization with an increase in technological knowledge (TK) was less than when CI was high.

Our third hypothesis suggested that foreign market knowledge moderate's technological knowledge and internationalization relationship. In Model 2 of Table 3, since the beta coefficient of the interaction effect of technological knowledge and foreign market knowledge is positive and significant $(\beta=0.135, \mathrm{p}<0.01)$, we receive evidence supporting the third hypothesis. Furthermore, as shown in Figure 3, when foreign market knowledge (FMK) is low, an increase in internationalization with an increase in TK is low, compared to when FMK is high.

As a measure of robustness, we also explored the relationship using change in internationalization as the dependent variable. Although the beta coefficient changed, however, overall statistical significance remained unchanged.

\section{Insert Figure 2 about here}


Insert Figure 3 about here

\section{Discussion and implications}

In this paper, we explore how in the spirit to manage and effectively utilize their technological knowledge in an institutional void-filled environment of the home country, EMFs internationalize. By confirming that EMFs' internationalization is positively associated with their technological knowledge, we support the view that, in the context of EMFs, specificities exist in how the firm's resources and capabilities support the process of international expansion (Contractor et al., 2007; Vrontis et al., 2020). Specifically, to avoid chances of technological knowledge spillover and expropriation by rival firms in voids filled institutional environment of India, firms rich in technological knowledge explore international markets to leverage their knowledge-based assets. We further find that foreign market knowledge and competitive intensity moderates this relationship.

\subsection{Theoretical implications}

For EMFs, it is contended that weak enforcement of formal institutions (e.g., codified laws and regulations) shape their international marketing strategies (Hart, 2005). In emerging markets, institutional voids explain the underdeveloped formal institutions, affecting how EMFs deploy their knowledge-based assets in international markets (Boso et al., 2018). Our findings highlight the role of "internationalization" as a knowledge management tool for EMFs. For protecting their technological knowledge in home markets, EMFs internationalize more as their technological investment increases. Our findings thus contribute to international marketing literature by 
explaining how the internationalization of EMFs is driven by the need of firms to safeguard their technological knowledge. Extant literature has emphasized the significance of knowledge management capabilities as a fundamental tool for supporting market operations (Vrontis et al., 2017). Our findings suggest internationalization itself can be a knowledge management tool for EMFs. This is because, in the presence of institutional voids, as EMFs technological capital increases, internationalization increases. This suggests that EMFs utilize technological knowledge is by internationalizing.

Extant international marketing literature has leveraged institutionalization theory to explain how weak institutions make EMFs thrive in challenging environments, which helps them overcome barriers in foreign markets and make internationalization more conducive (CuervoCazurra, 2012). We extend the implications of institutionalization theory and explain how EMFs safeguard their technological knowledge by internationalizing, as they suffer from institutional voids in emerging markets.

Second, our findings concerning competitive intensity as a moderator of the technological knowledge and internationalization relationship imply that increasing rivalry further drives them to avoid misappropriation of knowledge by exporting at an even faster rate. This way, our findings are consistent with previous literature that explores the influence of competitive intensity on firms' customer relationship management knowledge and supply chain effectiveness (Sanzo and Vázquez, 2011), though overall, only scant literature explores implications of competitive intensity on knowledge management strategies of the firm. We thus add to this stream of literature. The role of competitive intensity further elaborates on institutionalization theory. In a market that is only weakly legally protected, competitive intensity further enhances chances of technology 
misappropriation, thus further strengthening technology knowledge and internationalization relationship.

Third, as Barney’s (1991) resource-based theory suggests, for firms to compete effectively, they should possess rare (so few can possess it), imperfectly imitable, and non-substitutable resources. In general, firms reach such arrangements when resources are combined in particular ways so that they are difficult to imitate (Dyer and Singh 1998). In the context of EMFs, this implies that if firms are to get access to international markets, they must integrate technological knowledge with the foreign market knowledge embedded within their organizations (Barney et al., 2011). Integrating technological knowledge with foreign market knowledge would become a valuable resource for internationalization. EMFs would enhance both efficiencies and the effectiveness of their technological know-how, as their foreign market knowledge develops through investment in raising awareness of products and services or appropriate management of customer relations, helping EMFs in the effective deployment of their technological knowledge in international markets. This path-dependent learning sequence develops into a bundle through a combination of resources and would be embedded in firm-specific routines, thus increasing rarity and restricting imitability and substitutability (Collis 1994). We thus extend the implications of resource-based theory. In the past decade, foreign market literature has extensively leveraged the resource-based theory to explain how to gain advantages from existing resources, such as brand power or R\&D investment (Barney and Hesterly, 2012). However, studies exploring the integration of two resources as a driver of internationalization have only been scantly explored (Kozlenkova et al., 2014). By investigating the combined effect of technology knowledge and foreign market knowledge, we test resource-based theory in the context of combining two 
resources, namely technology knowledge and foreign market knowledge, and thus extend the literature on knowledge-based resources.

\subsection{Managerial implications}

Our study suggests three main implications for international marketing managers. First, EMFs can protect their technological knowledge by expanding their horizon to international markets. Thus, as EMFs technological knowledge increases, managers should seek internationalization to protect their technological knowledge to avoid the perils of institutional voids of the home country. Corollary, the presence of voids should not deter EMFs from developing technological assets but rectify institutional voids' downsides.

Overall, technology knowledge can become a prime driver of the internationalization of EMFs. Managers should constantly monitor their technology knowledge. Our findings suggest that one unit increase in technology knowledge increased internationalization by 0.18 units. So, as EMF managers develop technological knowledge, they should safeguard it by internationalizing. Shareholders should also promote firms rich in technological knowledge to protect the knowledge by venturing into international markets.

Second, as firms develop their knowledge-based assets, they should also seek to leverage their foreign market knowledge. This is because the combination of foreign market knowledge with technological knowledge (provide firms with better resource, which helps them to internationalization even more. Leveraging foreign market knowledge is necessary as it enhances the EMFs ability to utilize technological knowledge through internationalization.

Third our findings also suggest that managers should constantly and actively scan their

competitive environment. As they find increasing rivalry or competitive intensity, they should become more active in safeguarding their technological knowledge through internationalization. 
This is to avoid misappropriation and misutilization of their technological assets in emerging markets like India, where the poor institutional environment does not offer a protective shield to such assets.

\subsection{Limitations and directions of future research}

Our paper also has limitations that pave the directions for future research. The first limitation is we test our theoretical framework in only one of the emerging markets, where institutional voids exist in several emerging markets (Gao et al., 2017). Future studies should explore the issue in other emerging markets as well. A multi-country study would also help explore how changing institutional voids across countries requires technological knowledge management strategy changes.

Second, our theoretical framework can also be improved in two ways. In this paper, we considered only internationalization and not the entry mode affected by knowledge management motive. This was as we primarily asserted that internationalization would protect and manage technological knowledge in the home country (Meschi et al., 2017). Extant studies suggest that foreign market knowledge influences the mode of entry in international markets (Pehrsson, 2020). However, future studies could compare multiple entry modes in international markets, where the underlying motive is to protect and efficiently manage technological knowledge in international markets. For instance, Meyer et al. (2009) found that perceived market inefficiencies drive managers to decide entry mode in international markets.

Another way of improving our theoretical framework is to incorporate the source of foreign market knowledge. In this paper, we did not incorporate digital means of gaining foreign market knowledge. Internet is one of the most significant marketing tools that offers enormous potential for creating awareness of products in international markets (Bianchi and Mathews, 2016; Rodgers 
and Sheldon, 2002). Moreover, as firms switch to internet platforms for marketing in the digital economy, even in domestic markets, it has a spillover effect in international markets due to the global availability of free information on the internet (Elberse and Eliashberg, 2003). Future studies could use survey-based measures to segregate national versus international marketing strategies, to explore its influence on technological knowledge management strategy through internationalization for EMFs. Finally, firms can significantly enhance their knowledge management capabilities by enhancing tacit knowledge components, such as designing challenging and cognitively demanding configurations of work tasks. We do not capture such knowledge, and future studies could explore its role in driving firms' internationalization (Hernaus and Mikulić, 2014).

\section{Conclusion}

Our study was motivated by the lack of studies exploring technological knowledge management by EMFs, which is critical from the international marketing perspective (Leonidou et al., 2018). We provide an explanation that combines institutional theory (focusing on institutional voids) and resource-based theory. We argue that a poor institutional environment with a weak legal system increases EMFs' internationalization to manage their technological knowledge. We also find that firms' foreign market knowledge further drives them to internationalize with increased technological knowledge. Furthermore, competitive intensity in the home country also interacts

with technological knowledge. With increasing competitive intensity as chances of misappropriation increases, EMFs for protecting their technological knowledge internationalize more. 


\section{References}

Acquaah, M. (2007), "Managerial social capital, strategic orientation, and organizational performance in an emerging economy", Strategic Management Journal, Vol. 28 No. 12, pp. 1235-1255.

Adomako, S., Amankwah-Amoah, J., Dankwah, G.O., Danso, A. and Donbesuur, F. (2019), "Institutional voids, international learning effort and internationalization of emerging market new ventures", Journal of International Management, Vol. 25 No. 4, 100666.

Adomako, S., Amankwah-Amoah, J., Debrah, Y.A., Khan, Z., Chu, I. and Robinson, C. (2020), "Institutional voids, economic adversity and inter-firm cooperation in an emerging market: the mediating role of government R\&D support", British Journal of Management. https://doi.org/10.1111/1467-8551.12443

Amaeshi, K., Adegbite, E. and Rajwani, T. (2016), “Corporate social responsibility in challenging and non-enabling institutional contexts: do institutional voids matter?", Journal of Business Ethics, Vol. 134 No. 1, pp. 135-153.

Ang, S.H. (2008), "Competitive intensity and collaboration: impact on firm growth across technological environments", Strategic Management Journal, Vol. 29 No. 10, pp. 10571075.

Ashwin, A.S., Krishnan, R.T. and George, R. (2016), "Board characteristics, financial slack and R\&D investments: an empirical analysis of the Indian pharmaceutical industry", International Studies of Management \& Organization, Vol. 46 No. 1, pp. 8-23.

Auh, S. and Menguc, B. (2005), "Balancing exploration and exploitation: the moderating role of competitive intensity", Journal of Business Research, Vol. 58 No. 12, pp. 1652-1661.

Barney, J.B. (1991), "Firm resources and sustained competitive advantage", Journal of Management, Vol. 17 No. 1, pp. 99-120.

Barney, J.B. and Hesterly, W. (2012), Strategic Management and Competitive Advantage: Concepts and Cases (4th ed.). Pearson Publishing, New Jersey.

Barney, J.B., Ketchen Jr, D.J. and Wright, M. (2011), "The future of resource-based theory: revitalization or decline?", Journal of Management, Vol. 37 No. 5, pp. 1299-1315.

Beck, N. and Katz, J.N. (1995), "What to do (and not to do) with time-series cross-section data", American Political Science Review, Vol. 89 No. 3, pp. 634-647.

Berger, F., Blind, K. and Cuntz, A. (2012), "Risk factors and mechanisms of technology and insignia copying-A first empirical approach", Research Policy, Vol. 41 No. 2, pp. 376390.

Bhaumik, S.K., Driffield, N. and Pal, S. (2010), "Does ownership structure of emerging-market firms affect their outward FDI? The case of the Indian automotive and pharmaceutical sectors", Journal of International Business Studies, Vol. 41 No. 3, pp. 437-450.

Bianchi, C. and Mathews, S. (2016), "Internet marketing and export market growth in Chile", Journal of Business Research, Vol. 69 No. 2, pp.426-434.

Bierly III, P., Damanpour, F. and Santoro, D. (2009), "The application of external knowledge: organizational conditions for exploration and exploitation", Journal of Management Studies, Vol. 46 No. 3, pp. 481-509

Boisot, M. and Meyer, M.W. (2008), "Which way through the open door? Reflections on the internationalization of Chinese firms", Management and Organization Review, Vol. 4 No. 3, pp. 349-365. 
Bordoloi, P. and Islam, N. (2012), "Knowledge management practices and healthcare delivery: a contingency framework", The Electronic Journal of Knowledge Management, Vol. 10 No. 2, pp. 110-120.

Bortoluzzi, G., Chiarvesio, M., Di Maria, E. and Tabacco, R. (2014), "Exporters moving toward emerging markets: a resource-based approach", International Marketing Review, Vol. 31 No. 5, pp. 506-525.

Bortoluzzi, G., Kadic-Maglajlic, S., Arslanagic-Kalajdzic, M. and Balboni, B. (2018), "Innovativeness as a driver of the international expansion of developing markets' firms", International Marketing Review, Vol. 35 No. (2), pp. 215-235.

Boso, N., Danso, A., Leonidou, C., Uddin, M., Adeola, O. and Hultman, M. (2017), "Does financial resource slack drive sustainability expenditure in developing economy small and medium-sized enterprises?", Journal of Business Research, Vol. 80, pp. 247-256.

Boso, N., Debrah, Y.A. and Amankwah-Amoah, J. (2018), "International marketing strategies of emerging market firms. International Marketing Review, Vol. 35 No. (2), pp. 202-214.

Boso, N., Story, V.M. and Cadogan, J.W. (2013), "Entrepreneurial orientation, market orientation, network ties, and performance: study of entrepreneurial firms in a developing economy", Journal of Business Venturing, Vol. 28 No. 6, pp. 708-727.

Bruton, G.D., Ketchen Jr, D.J., and Ireland, R.D. (2013), "Entrepreneurship as a solution to poverty", Journal of Business Venturing, Vol. 28 No. 6, pp. 683-689.

BSE India. (2011), "Criteria for "A" group companies", https://www.bseindia.com/downloads/About/file/Criteria_for_Group_A.pdf

Burgers, J.H., Van Den Bosch, F.A.J., and Volberda, H.W. (2008), "Why new business development projects fail: coping with the differences of technological and market knowledge", Long Range Planning, Vol. 41 No. 1, pp. 55-73

Carr, J.C., Haggard, K.S., Hmieleski, K.M. and Zahra, S.A. (2010), “A study of the moderating effects of firm age at internationalization on firm survival and short-term growth", Strategic Entrepreneurship Journal, Vol. 4 No. 2, pp. 183-192.

Castellacci, F. (2012), "Business groups, innovation and institutional voids in Latin America (MPRA Paper $\quad$ No. 41481”, muenchen.de/41481/1/MPRA_paper_41481.pdf

Castellacci, F. and Natera, J.M. (2012), "Innovation surveys in Latin America: a primer", Innovation and Development, Vol. 2 No. 1, pp. 199-204.

Chan, C.S. and Pattnaik, C. (2021), "Coevolution of home country support and internationalization of emerging market firms", International Business Review, Vol. 30 No. 4, 101809.

Chari, M.D. (2013), "Business groups and foreign direct investments by developing country firms: an empirical test in India", Journal of World Business, Vol. 48 No. 3, pp. 349-359.

Chatterjee, S. Chaudhuri, R. and Vrontis, D. (2021), "Does Data-driven Culture Impact Innovation and Performance of a Firm? An Empirical Examination" Annals of Operations Research, Vol. ahead-of-print No. ahead-of-print. https://doi.org/10.1007/s10479-020-03887-z

Chauvel, D. and Despres, C. (2002), "A review of survey research in knowledge management: 1997-2001”, Journal of Knowledge Management, Vol. 6 No. 3, pp. 207-223.

Chen, W.R. and Miller, K.D. (2007), "Situational and institutional determinants of firms' R\&D search intensity”, Strategic Management Journal, Vol. 28 No. 4, pp. 369-381. 
Chittoor, R. and Ray, S. (2007), "Internationalization paths of Indian pharmaceutical firms-A strategic group analysis", Journal of International Management, Vol. 13 No. 3, pp. 338355.

Choi, K., Jean, R.J.B. and Kim, D. (2019), "The impacts of organizational learning capacities on relationship-specific innovations". International Marketing Review, Vol. 36 No. 6, 10421066.

Christofi, M., Vrontis, D. and Cadogan, J. (2021), "Micro-foundational ambidexterity and multinational enterprises: a systematic review and a conceptual framework", International Business Review, Vol. 30, No. 1, 101625.

Clarysse, B., Wright, M. and Van de Velde, E. (2011), "Entrepreneurial origin, technological knowledge, and the growth of spin-off companies", Journal of Management Studies, Vol. 48 No. 6, pp. 1420-1442.

CMIE. (2019), "ProwessIQ database dictionary Annual Financial Statements (Ind AS)", CMIE.

Cohen, W.M. and Levinthal, D.A. (1990), "Absorptive capacity: a new perspective on learning and innovation", Administrative Science Quarterly, Vol. 35 No. 1, pp. 128-152

Cohen, W.M., Nelson, R.R. and Walsh, J.P, (2000), "Protecting their intellectual assets: appropriability conditions and why firms patent or not? (Working Paper No. 7552)", NBER. https://www.nber.org/papers/w7552

Collis, D.J. (1994), "Research note: how valuable are organizational capabilities?", Strategic Management Journal, Vol. 15 No. (S1), pp. 143-152.

Contractor, F.J., Kumar, V. and Kundu, S.K. (2007), "Nature of the relationship between international expansion and performance: the case of emerging market firms", Journal of World Business, Vol. 42 No. 4, pp. 401-417.

Cuervo-Cazurra, A. (2012), "Extending theory by analyzing developing country multinational companies: Solving the Goldilocks debate", Global Strategy Journal, Vol. 2 No. 3, pp. 153-167.

Day, G.S. (1994), “The capabilities of market-driven organizations”, Journal of Marketing, Vol. 58 No. 4, pp. 37-52.

Dau, L.A. (2012), "Pro-market reforms and developing country multinational corporations", Global Strategy Journal, Vol. 2 No. 3, pp. 262-276.

Deng, P. and Zhang, S. (2018), "Institutional quality and internationalization of emerging market firms: Focusing on Chinese SMEs", Journal of Business Research, Vol. 92, pp. 279-289.

Doh, J., Rodrigues, S., Saka-Helmhout, A., and Makhija, M. (2017), "International business responses to institutional voids", Journal of International Business Studies, Vol. 48, 293307.

Dyer, J.H. and Singh, H. (1998), "The relational view: cooperative strategy and sources of interorganizational competitive advantage", Academy of Management Review, Vol. 23 No. 4, pp. 660-679.

Elberse, A. and Eliashberg, J. (2003), "Demand and supply dynamics for sequentially released products in international markets: the case of motion pictures", Marketing Science, Vol. 22 No. 3, pp.329-354.

Eriksson, K. and Chetty, S. (1998), "The development of experiential knowledge in internationalization through customer-supplier relationship", In Proceedings of the 27th EMAC Conference, Track 2, International Marketing, Stockholm, Sweden. 
Gao, C., Zuzul, T., Jones, G. and Khanna, T. (2017), "Overcoming institutional voids: a reputationbased view of long-run survival”, Strategic Management Journal, Vol. 38 No. 11, pp. 2147-2167.

Gast, J., Gundolf, K., Harms, R. and Collado, E.M. (2019), "Knowledge management and coopetition: How do cooperating competitors balance the needs to share and protect their knowledge?", Industrial Marketing Management, Vol. 77, pp. 65-74.

Gaur, A.S., Kumar, V. and Singh, D. (2014), "Institutions, resources, and internationalization of emerging economy firms”, Journal of World Business, Vol. 49 No. 1, pp. 12-20.

Goldberg, P., Khandelwal, A., Pavcnik, N., and Topalova, P. (2009), “Trade liberalization and new imported inputs", American Economic Review, Vol. 99 No. 2, pp. 494-500.

Greene, W.H. (2000), Econometric Analysis, Prentice Hall, Upper Saddle River, NJ.

Griffith, D.A., Kiessling, T. and Dabic, M. (2012), "Aligning strategic orientation with local market conditions: implications for subsidiary knowledge management", International Marketing Review, Vol. 29 No. 4, pp. 379-402.

Groł̀nhaug, K. and Nordhaug, O. (1992), "Strategy and competence in firms", European Management Journal, Vol. 10 No. 4, pp. 438-44

Guedes, M.J., da Conceição Gonçalves, V., Soares, N., and Valente, M. (2016), "UK evidence for the determinants of R\&D intensity from a panel fsQCA", Journal of Business Research, Vol. 69 No. 11, pp. 5431-5436.

Hånell, S.M., Nordman, E.R. and Mattsson, L.G. (2020), “The nature of individual experiential knowledge in internationalizing SMEs: pitfalls of superstitious learning and the need for wisdom", International Marketing Review. Vol. ahead-of-print No. ahead-of-print. https://doi.org/10.1108/IMR-02-2019-0086

Hart, S.L. (2005), Capitalism At the Crossroads: The Unlimited Business Opportunities in Solving the World's Most Difficult Problems, Pearson Education, New York.

Hernaus, T. and Mikulić, J. (2014), "Work characteristics and work performance of knowledge workers", EuroMed Journal of Business, Vol. 9 No. 3, pp. 268-292.

Hitt, M.A., Li, H. and Worthington IV, W.J. (2005), "Emerging markets as learning laboratories: learning behaviors of local firms and foreign entrants in different institutional contexts", Management and Organization Review, Vol. 1 No. 3, pp. 353-380.

Ipek, I. and Tanyeri, M. (2020), "Home country institutional drivers and performance outcomes of export market orientation: the moderating role of firm resources", International Journal of Emerging Markets, Vol. ahead-of-print No. ahead-of-print. https://doi.org/10.1108/IJOEM-10-2019-0803

Jiang, M.S. and Menguc, B. (2012), "Brand as credible commitment in embedded licensing: a transaction cost perspective", International Marketing Review, Vol. 29 No. 2, 134-150.

Jones, E. and De Wit, H. (2012), "Globalization of internationalization: thematic and regional reflections on a traditional concept", AUDEM: The International Journal of Higher Education and Democracy, Vol. 3 No. 1, pp. 35-54.

Jones, G. (2012), "The growth opportunity that lies next door", Harvard Business Review, Vol. 90 No. 7-8, pp. 141-145.

Karagouni, G., Protogerou, A. and Caloghirou, Y. (2013), “Autotelic capabilities and their impact on technological capabilities", EuroMed Journal of Business, Vol. 8 No. 1, pp. 48-63.

Kaufmann, R., Tarba, S., Yeheskel, O. and Shenkar, O. (2009), "Knowledge flows in international business: a JIBS citation analysis", EuroMed Journal of Business, Vol. 4 No. 2, pp. 111126. 
Keats, B.W. and Hitt, M.A. (1988), "A causal model of linkages among environmental dimensions, macro organizational characteristics, and performance. Academy of Management Journal, Vol. 31 No. 3, pp. 570-598.

Khanna, T. and Palepu, K. (2000), "Is group affiliation profitable in emerging markets? An analysis of diversified Indian business groups", The Journal of Finance, Vol. 55 No. 2, pp. 867-891.

Kozlenkova, I.V., Samaha, S.A. and Palmatier, R.W. (2014), "Resource-based theory in marketing", Journal of the Academy of Marketing Science, Vol. 42 No. 1, pp. 1-21.

Krasnikov, A. and Jayachandran, S. (2008), "The relative impact of marketing, research-anddevelopment, and operations capabilities on firm performance", Journal of Marketing, Vol. 72 No. 4, pp. 1-11.

Kumar, N. and Aggarwal, A. (2005), "Liberalization, outward orientation and in-house R\&D activity of multinational and local firms: a quantitative exploration for Indian manufacturing", Research Policy, Vol. 34 No. 4, pp. 441-460.

Lee, H. and Choi, B. (2003), "Knowledge management enablers, processes, and organizational performance: an integrative view and empirical examination", Journal of Management Information Systems, Vol. 20 No. 1, pp. 179-228.

Lee, S.H., Makhija, M. and Paik, Y. (2008), "The value of real options investments under abnormal uncertainty: the case of the Korean economic crisis", Journal of World Business, Vol. 43 No. 1, pp. 16-34.

Leonidou, L.C., Katsikeas, C.S., Samiee, S. and Aykol, B. (2018), "International marketing research: a state-of-the-art review and the way forward", In: Leonidou, L.C., Katsikeas, C.S., Samiee, S. and Aykol, B. (eds), Advances in Global Marketing. Springer, Cham, pp. 3-33.

Li, J. and Xie, Z. (2011), "Global R\&D strategies in an emerging economy: The development and protection of technological competencies", European Management Review, Vol. 8 No. 3, pp. 153-164.

Li, T. and Cavusgil, S.T. (1995), "A classification and assessment of research streams in international marketing”, International Business Review, Vol. 4 No. 3, pp. 251-277.

Lounsbury, M. (2002), "Institutional transformation and status mobility: the professionalization of the field of finance", Academy of Management Journal, Vol. 45 No. 1, pp. 255-266.

MacGarvie, M. (2006), "Do firms learn from international trade?", Review of Economics and Statistics, Vol. 88 No. 1, pp. 46-60.

Mair, J. and Marti, I. (2009), "Entrepreneurship in and around institutional voids: a case study from Bangladesh", Journal of Business Venturing, Vol. 24 No. 5, pp. 419-435.

Manos, R., Murinde, V. and Green, C.J. (2007), "Leverage and business groups: Evidence from Indian firms", Journal of Economics and Business, Vol. 59 No. 5, pp. 443-465.

Mariadoss, B.J., Tansuhaj, P.S. and Mouri, N. (2011), "Marketing capabilities and innovationbased strategies for environmental sustainability: an exploratory investigation of B2B firms", Industrial Marketing Management, Vol. 40 No. 8, pp. 1305-1318.

Marsili, O. and Verspagen, B. (2002), "Technology and the dynamics of industrial structures: an empirical mapping of Dutch manufacturing”, Industrial and Corporate Change, Vol. 11 No. 4, pp. 791-815.

Meschi, P.X., Ricard, A and Moore, E.T. (2017), "Fast and furious or slow and cautious? The joint impact of age at internationalization, speed, and risk diversity on the survival of exporting firms", Journal of International Management, Vol. 23 No. 3, pp. 279-291. 
Meyer, K.E., Estrin, S., Bhaumik, S.K. and Peng, M.W. (2009), "Institutions, resources, and entry strategies in emerging economies", Strategic Management Journal, Vol. 30 No. 1, pp. 6180 .

Mohrman, S.A. and Von Glinow, M.A. (1990), "High technology organizations: context, organization and people", Journal of Engineering and Technology Management, Vol. 6 No. 3-4, pp. 261-280.

Mostafiz, M.I., Sambasivan, M. and Goh, S.K. (2021), "Antecedents and consequences of market orientation in international B2B market: role of export assistance as a moderator", Journal of Business \& Industrial Marketing, Vol. 36 No. 6, pp. 1058-1075.

Narayanan, V. (2001), Managing Technology and Innovation for Competitive Advantage, Prentice-Hall, New York.

North, D.C. (1990), Institutions, Institutional Change and Economic Performance, Cambridge University Press, New York.

O'Cass, A., Ngo, L.V. and Siahtiri, V. (2015), "Marketing resource-capability complementarity and firm performance in B2B firms" Journal of Business \& Industrial Marketing, Vol. 30 No. 2, pp. 194-207.

Pehrsson, A. (2020), “An acquisition or a greenfield subsidiary? The impact of knowledge on sequential establishments in a host country", International Marketing Review, Vol. 37 No. 2, pp. 377-396.

Ramani, N. and Srinivasan, R. (2019), 'Effects of liberalization on incumbent firms' MarketingMix responses and performance: evidence from a quasi-experiment" Journal of Marketing, Vol. 83 No. 5, pp. 97-114.

Ray, S., Mondal, A. and Ramachandran, K. (2018), "How does family involvement affect a firm's internationalization? An investigation of Indian family firms", Global Strategy Journal, Vol. 8 No. 1, pp. 73-105.

Rodgers, S. and Sheldon, K.M. (2002), "An improved way to characterize Internet users”, Journal of Advertising Research, Vol. 42 No. 5, pp.85-94.

Sanzo, M.J. and Vázquez, R. (2011), "The influence of customer relationship marketing strategies on supply chain relationships: the moderating effects of environmental uncertainty and competitive rivalry", Journal of Business-to-Business Marketing, Vol. 18 No. 1, pp. 50-82.

Scott, W.R. (1995), Institutions and Organizations, Sage, Thousand Oaks, CA.

Shankar, V. and Narang, U. (2019), "Emerging market innovations: Unique and differential drivers, practitioner implications, and research agenda", Journal of the Academy of Marketing Science, Vol. 48, pp. 1030-1052.

Shieh, G. (2010), "On the misconception of multicollinearity in detection of moderating effects: multicollinearity is not always detrimental", Multivariate Behavioral Research, Vol. 45 No. 3, pp. 483-507.

Smith, P.J. (2001), "How do foreign patent rights affect U.S. exports, affiliate sales, and licenses?”, Journal of International Economics, Vol. 55 No. 2, pp. 411-439.

Song, M., Nason, R.W. and Di Benedetto, C.A. (2008), "Distinctive marketing and information technology capabilities and strategic types: a cross-national investigation", Journal of International Marketing, Vol. 16 No. 1, pp. 4-38.

Steen, J.T. and Liesch, P.W. (2007), "A note on Penrosean growth, resource bundles and the Uppsala model of internationalization”, Management International Review, Vol. 47 No. 2, pp. 193-206. 
Stewart Jr, W.H., May, R.C. and Kalia, A. (2008), "Environmental perceptions and scanning in the United States and India: convergence in entrepreneurial information seeking?" Entrepreneurship Theory and Practice, Vol. 32 No. 1, pp. 83-106.

Styles, C., Mittelstaedt, J.D., Ward, W.A., \& Nowlin, E. (2006). Location, industrial concentration and the propensity of small US firms to export. International Marketing Review, Vol. 23 No. 5, 486-503.

Theodosiou, M. and Katsikea, E. (2013), "The export information system: An empirical investigation of its antecedents and performance outcomes", Journal of International Marketing, Vol. 21 No. 3, pp. 72-94.

Vrontis, D., Basile, G., Andreano, S., Mazzitelli, M. and Papasolomou, I. (2020), "The Profile of Innovation Driven Italian SMEs and the Relationship Between the Firms' Networking Abilities and Dynamic Capabilities", Journal of Business Research, Vol. 114, pp. 313-324.

Vrontis, D. and Christofi, M. (2019), "R\&D Internationalization and Innovation: a Systematic Review, Integrative Framework and Future Research Direction”, Journal of Business Research, Vol. ahead-of-print No. ahead-of-print, https://doi.org/10.1016/j.jbusres.2019.03.031

Vrontis, D., Christofi, M., Battisti, E. and Graziano, E.A. (2020), "Intellectual Capital, Knowledge Sharing and Equity Crowdfunding”, Journal of Intellectual Capital, Vol. 22 No. 1, pp. 95121.

Vrontis, D., Thrassou, A., Chebbi, H. and Yahiaoui, D. (2012), "A Preliminary Strategic Marketing Framework for New Product Development", Journal of Transnational Management, Vol. 17, No. 1, pp. 21-44

Vrontis, D., Thrassou, A., Santoro, G. and Papa, A. (2017), “Ambidexterity, external knowledge and performance in knowledge-intensive firms", The Journal of Technology Transfer, Vol. 42 No. 2, pp. 374-388.

Wadhwa, P., McCormick, M. and Musteen, M. (2017), "Technological innovation among internationality active SMEs in the Czech economy", European Business Review, Vol. 29 No. 2, pp. 164-180.

Witt, M.A. and Lewin, A.Y. (2007), "Outward foreign direct investment as escape response to home country institutional constraints", Journal of International Business Studies, Vol. 38 No. 4, pp. 579-594.

Wright, M., Filatotchev, I., Hoskisson, R. E. and Peng, M.W. (2005), "Strategy research in emerging economies: challenging the conventional wisdom", Journal of Management Studies, Vol. 42 No. 1, pp. 1-33.

Wright, P., Kroll, M., Lado, A. and Elenkov, D. (2005), "Influences of relative rewards of top managers on firm performance", Strategic Organization, Vol. 3 No. 3, pp. 311-335.

Yan, Z.J., Zhu, J.C., Fan, D. and Kalfadellis, P. (2018), “An institutional work view toward the internationalization of emerging market firms", Journal of World Business, Vol. 53 No. 5, pp. 682-694.

Zhou, L. (2007), "The effects of entrepreneurial proclivity and foreign market knowledge on early internationalization", Journal of World Business, Vol. 42 No. 3, pp. 281-293.

Zou, H. and Ghauri, P.N. (2008), "Learning through international acquisitions: the process of knowledge acquisition in China", Management International Review, Vol. 48 No. 2, pp. 207-226. 
Table 1: Operationalization of variables

\begin{tabular}{|c|c|c|}
\hline Variable & Operationalization & Source \\
\hline $\begin{array}{c}\text { Growth in } \\
\text { internationalization }\end{array}$ & Growth in foreign assets to total assets & Bhaumik et al. (2010) \\
\hline $\begin{array}{l}\text { Technological } \\
\text { knowledge }\end{array}$ & Natural log of net technical knowhow & CMIE (2019) \\
\hline $\begin{array}{l}\text { Competitive } \\
\text { Intensity }\end{array}$ & $\begin{array}{c}\text { 1- HERF, where HERFF = sum } \\
\text { of squared market shares for all } \\
\text { the firms in an industry }\end{array}$ & Engelen et al. (2012) \\
\hline $\begin{array}{c}\text { Foreign market } \\
\text { knowledge }\end{array}$ & $\begin{array}{l}\text { Ratio of the sum of foreign exchange } \\
\text { spending and foreign exchange } \\
\text { earnings divided by total assets }\end{array}$ & Ramani and Srinivasan (2019) \\
\hline Firm age & $\begin{array}{l}\text { Natural log of the number of years } \\
\text { since the focal firm's inception }\end{array}$ & Carr et al. (2010) \\
\hline Firm size & $\begin{array}{c}\text { Natural log of the number of } \\
\text { employees }\end{array}$ & Carr et al. (2010) \\
\hline $\begin{array}{l}\text { Business Group } \\
\text { affiliation }\end{array}$ & $\begin{array}{c}\text { Dummy code of } 1 \text { for group affiliated } \\
\text { firm, else zero }\end{array}$ & Gaur et al. (2014) \\
\hline Leverage & Debt-to-equity ratio & Manos et al. (2007) \\
\hline Financial slack & Current ratio & Ashwin et al. (2016) \\
\hline
\end{tabular}


Table 2. Descriptive statistics and correlation matrix $(n=1,956)$

\begin{tabular}{|c|c|c|c|c|c|c|c|c|c|c|}
\hline & & 1 & 2 & 3 & 4 & 5 & 6 & 7 & 8 & 9 \\
\hline 1 & Growth in internationalization & 1 & & & & & & & & \\
\hline 2 & Technological knowledge (Ln) & 0.321 & 1 & & & & & & & \\
\hline 3 & Foreign market knowledge & 0.245 & 0.231 & 1 & & & & & & \\
\hline 4 & Competitive intensity & 0.156 & 0.116 & 0.108 & 1 & & & & & \\
\hline 5 & Firm age (Ln) & 0.08 & 0.093 & 0.037 & 0.003 & 1 & & & & \\
\hline 6 & Firm size (Ln) & 0.071 & 0.072 & 0.024 & 0.004 & 0.083 & 1 & & & \\
\hline 7 & Financial slack & 0.102 & 0.061 & 0.055 & 0.007 & 0.041 & 0.032 & 1 & & \\
\hline 8 & Leverage & 0.051 & 0.003 & 0.004 & 0.017 & 0.074 & 0.079 & 0.014 & 1 & \\
\hline \multirow[t]{3}{*}{9} & Business group affiliation & 0.101 & 0.075 & 0.104 & 0.062 & 0.083 & 0.046 & 0.024 & 0.048 & 1 \\
\hline & Mean & 0.58 & 7.3 & 0.247 & 0.334 & 3.41 & 6.81 & 2.6 & 1.8 & 0.64 \\
\hline & S.D. & 3.45 & 9.1 & 0.38 & 0.216 & 0.48 & 2.73 & 3.1 & 2.01 & 0.45 \\
\hline
\end{tabular}

$\mathrm{r}-0.06-0.07, \mathrm{p}<0.01, \mathrm{r}-0.08$ onwards, $\mathrm{p}<0.001, \mathrm{r}-0.04, \mathrm{p}<0.10, \mathrm{r}-0.05, \mathrm{p}<0.05$ 
Table 3. Results of GLS regression analysis $(n=1,956)$

\begin{tabular}{cccc}
\hline D.V. Growth in internationalization & Model 0 & Model 1 & Model 2 \\
\hline Technological knowledge & & $0.193^{* * *}$ & $0.195^{* * *}$ \\
& & $(0.055)$ & $(0.056)$ \\
Foreign market knowledge & & $0.105^{* *}$ & $0.106^{* *}$ \\
& & $(0.033)$ & $(0.034)$ \\
Competitive intensity & & $0.05^{* *}$ & $0.05^{* *}$ \\
& & $(0.016)$ & $(0.016)$ \\
Technological knowledge*Foreign market knowledge & & & $0.135^{* *}$ \\
& & & $(0.044)$ \\
Technological knowledge*Competitive intensity & & & $0.093^{* *}$ \\
& & & $(0.03)$ \\
Firm age (Ln) & 0.018 & 0.019 & 0.019 \\
& $(0.012)$ & $(0.013)$ & $(0.013)$ \\
Firm size (Ln) & 0.009 & 0.01 & 0.01 \\
& $(0.006)$ & $(0.007)$ & $(0.007)$ \\
Business group affiliation & $0.078^{* *}$ & $0.079^{* *}$ & $0.080^{* *}$ \\
Leverage & $(0.025)$ & $(0.026)$ & $(0.027)$ \\
& 0.052 & 0.053 & 0.055 \\
Financial slack & $(0.037)$ & $(0.038)$ & $(0.04)$ \\
Industry & $0.073^{*}$ & $0.075^{* *}$ & $0.077^{*}$ \\
Year & $(0.033)$ & $(0.035)$ & $(0.036)$ \\
Adjusted $\boldsymbol{R}$-square & Yes & Yes & Yes \\
F-Statistics & Yes & Yes & Yes \\
& 0.108 & 0.188 & 0.202 \\
& 10.527 & 17.205 & 17.574 \\
\hline
\end{tabular}

${ }^{* * *}, \mathrm{p}<0.001, * *, \mathrm{p}<0.01, *, \mathrm{p}<0.05 ;$ s.e. in parenthesis 
Figure 1. Conceptual framework

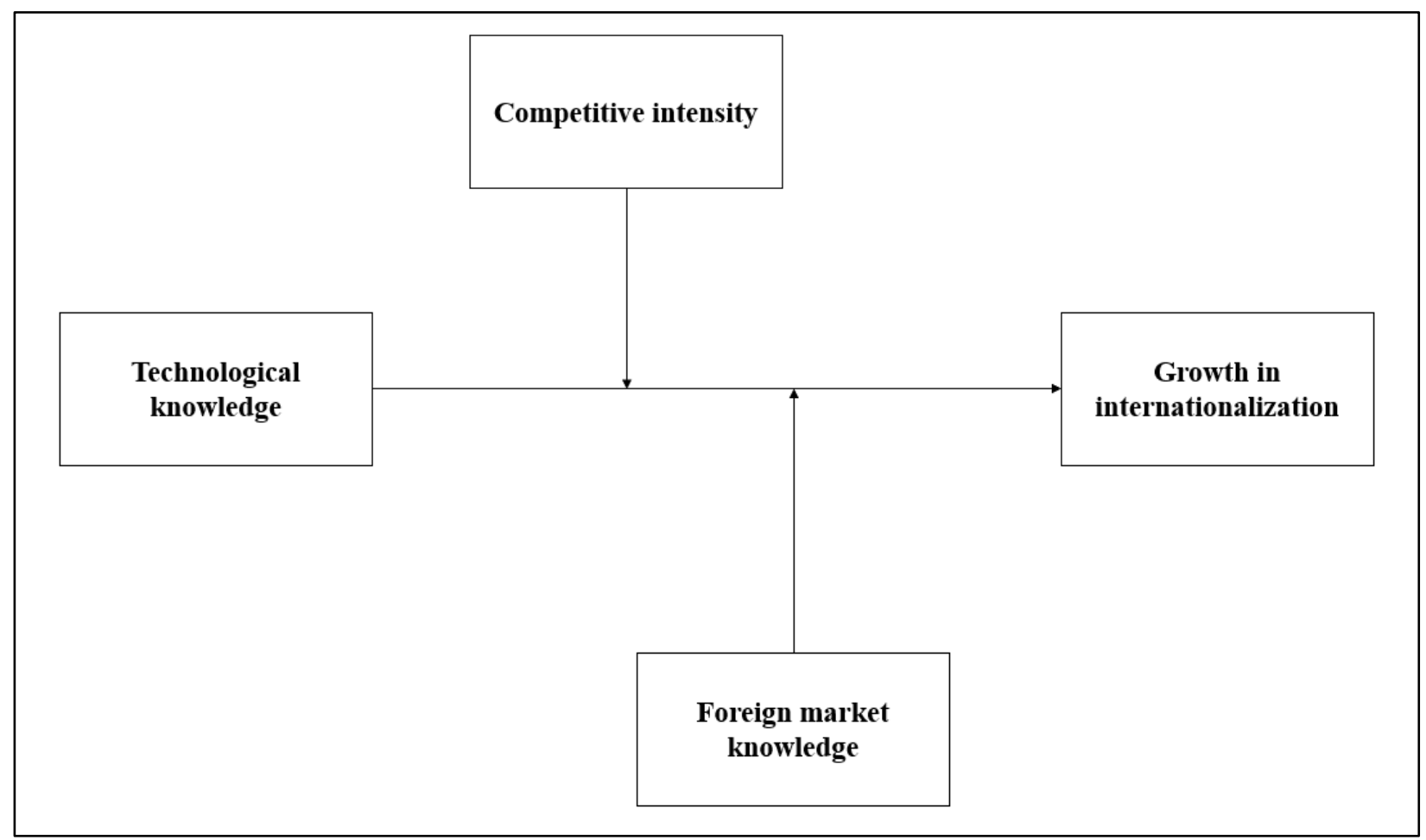


Figure 2. Moderating impact of competitive intensity on technological knowledge and growth in internationalization relationship

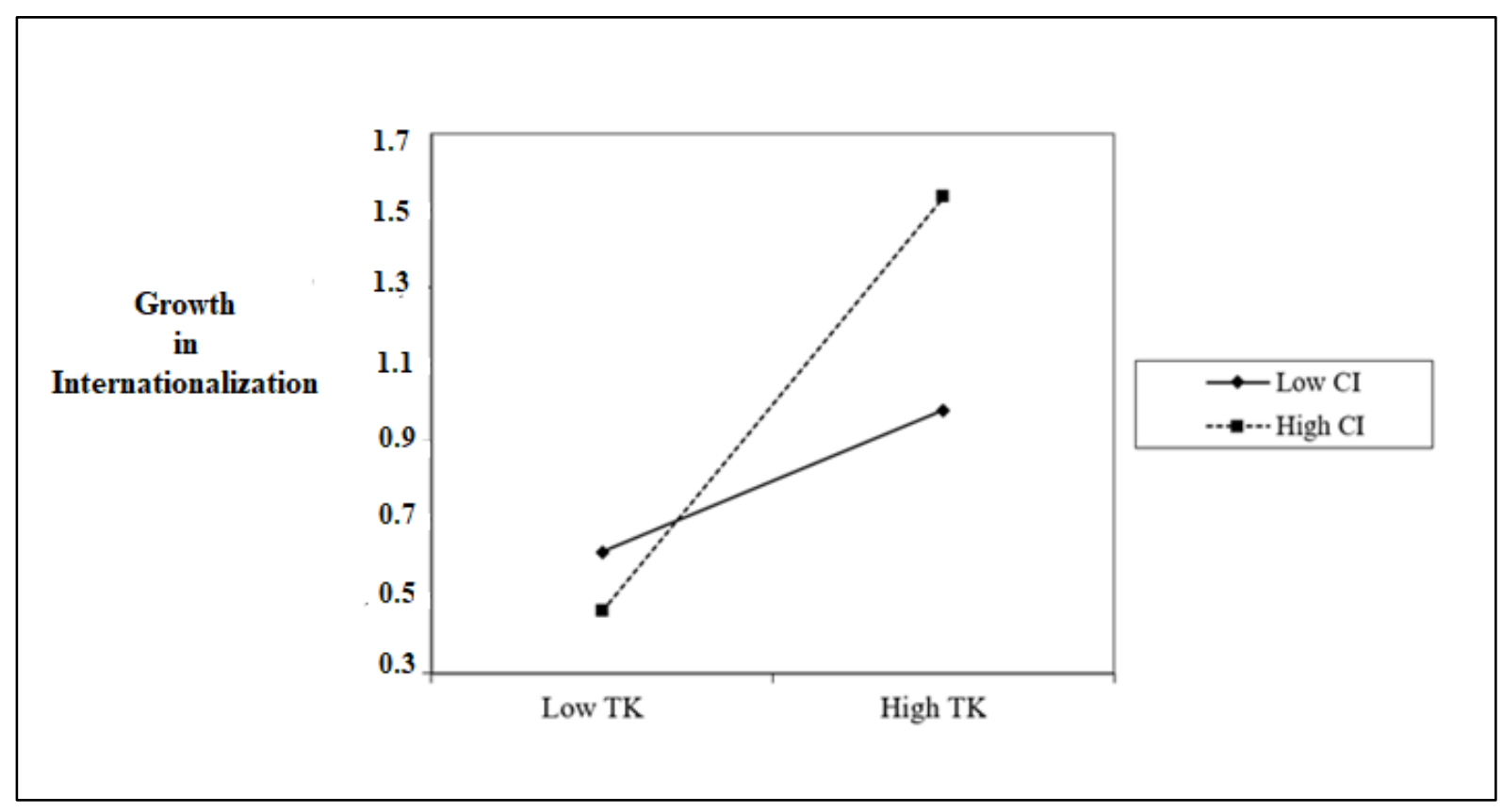


Figure 3. Moderating impact of foreign market knowledge on technological knowledge and growth in internationalization relationship

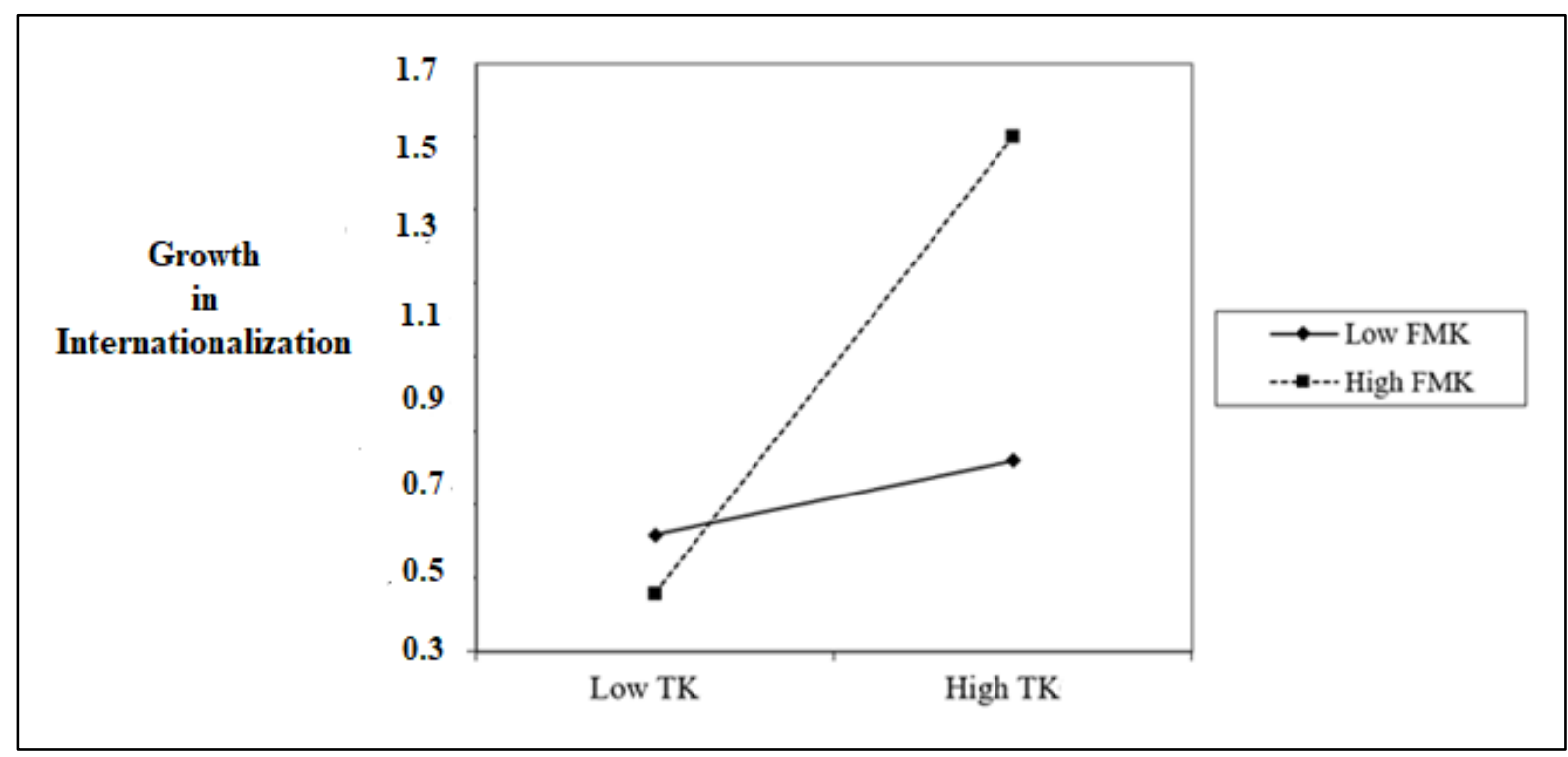

